\title{
Accrual Accounting at Government: a Bibliometric Study
}

\author{
Rindu Rika Gamayuni ${ }^{1}$ \\ \{rindu.gamayuni@yahoo.com $\left.{ }^{1}\right\}$ \\ Faculty of Economics and Business, University of Lampung, Jl. SumantriBrojonegoro, Bandar lampung, Indonesia ${ }^{1}$
}

\begin{abstract}
This research is a bibliometric analysis study of accrual accounting in government financial reporting. The purpose of this research is to examine the development of research in this field as a basis for determining the direction of further research. Phenomenon that occurs is the benefits of implementing accrual accounting in government which aims to produce information for decision making, is still a debate. In the previous research, there is no bibliometric analysis on the development of government accrual accounting. The research methodology was carried out with bibliometric analysis conducted on 200 Scopus indexed papers published between 2010 and 2019. The Finding is there are 7 clusters of study areas on government accrual accounting with different levels of theoretical maturity. So research on Government accrual accounting still needs to be researched more deeply at this time regarding the benefits of accrual accounting for decision making.
\end{abstract}

Keywords: accrual accounting, government, decision usefulness

\section{Introduction}

After decades of New Public Management (NPM) changes, the public management model has been criticized and this financial information has not been able to meet demand. Research study before still debating about accrual accounting in public sector and still have not any conclussion [1]-[4]. As the results of previous research concluded that users have more cash-based information in budgeting than accrual basis[5]. However, several studies have found the opposite, that accrual-based financial reports are more useful than cash-based financial reports[6]. Thus, further evidence is needed regarding the benefits of accrual basis financial statements for decision making. The purpose of this paper is to provide a bibliometric analysis of the literature and answer the following questions: 1 . How is the classiffication of articles related to accrual accounting in government, 2 . What is the trend of the research topics, 3. What is the possibility of research related to accrual accounting that can be done in the future?

\section{Literature Review}

\subsection{Accrual accounting versus cash accounting}

Since 1980 the orientation of public sector accounting has been towards accrual accounting. Starting in Australia and New Zealand in the 1990s, because accrual accounting was claimed to provide better information. Where in the cash basis system there is an inherent bias towards capital investment and that information provided through accrual accounting provides better information regarding decisions about the balance between current and capital expenditures, taking into account the opportunity cost of capital and its consumption over time[2]. The emergence of accrual accounting is to overcome the weakness of cash basis accounting in tracking expenditure efficiency. The main drawback of cash basis accounting is that this system only calculates shortterm cash flows, such as ongoing receipts and payments, but ignores financial cash flows that do not include cash movements such as depreciation, asset write-offs, and accrued interest. In previous research study, [1], cash-based accounting is also considered to lack of information in the presentation of financial statements because cash-based accounting is only intended to report budget use. The reporting period is short-term oriented and cannot provide complete information regarding government performance. The existence of this underreported information results in low accountability and transparency and can lead to corruption. Corruption destroys public funds. This weakness can be overcome with the accrual accounting basis to protect the public interest.

However,[7]argues that accrual accounting in the public sector is more inferior and inappropriate because in the public sector, profit is not the main goal, so profit is not a relevant measure of performance in the public sector. 
Likewise, the finnacial structure and solvency (ability to repay debt) are irrelevant to the realm of the public sector. This opinion is in line with[8]that accrual accounting provides limited idea of performance, focus on service costs and efficiency. Accrual accounting cannot solve the problem of financial control, but it will worsen because accrual accounting provides a broader scope of assessments that can attract politicians to be more flexible in window dressing. Despite some arguments against the merits of accrual accounting, there is a debate that there is a pressure on the public sector accounting to reform and demonstrate effectiveness and efficiency through the application of accrual basis[9].

According to[10] there are two groups of bennefit of implementing accrual basis accounting in government. The first group of bennefit is related to internal and external transparency. In several previous studies, it was stated that accrual accounting can measure fiscal transparency. The second bennefit group is related to decision making. Because accrual accounting helps identify the full cost of an activity, it can improve decision-making regarding resource allocation, improve governance control and better capital investment decisions.

\subsection{Institutional Theory}

Institutional theory considers expectations and values, both inside and outside of the organization, as societal rules can play a role in decisions to introduce organizational changes regarding the accounting system. Institutional theory is used by many researchers to explain organizational change, namely how organizations respond to pressures from their institutional environment[11]. Isomorphism is the tendency of an organization towards uniformity with respect to its environment and institutions[12]. Isomorphism can occur with the following mechanisms: (1) Coercive, which is generated from formal and informal pressure on an organization by other organizations and the expectations of society, in legal, economic and political contexts, formal and informal by the state, which will lead the organization to make decisions for adopting certain practices., (2) Normative, which arises from professionalism that forms a set of norms and procedures, which occurs as a result of sharing of values and ideas between professional and academic groups., (3) Imitative, which occurs in conditions of uncertainty and instability, when one organization imitates the proven and successful practices of other similar organizations.

\subsection{Decision Usefulness}

As explained in the conceptual framework of accounting standard-setting bodies, the purpose of financial reporting by public sector entities is to provide information related to the entity, which is useful to its users. In this context, usefulness is assessed in terms of decision making and accountability. [7] argues that although the public sector is clasified as neutral in decision making, in reality it cannot be neutral in terms of social, economic and political matters. Another thing that affects decision making is the nature of the basis of accounting used in producing this information. In this case, the use of an accounting basis based on cash or accruals will result in differences in the financial statements presented and of course have an impact on different decision making. Different groups need different information they also view and assess the information presented in different ways. Some groups of users of accounting information are government agencies, investors and creditors, resource providers, and regulatory agencies[5].

\section{Methodology and Data Analysis}

This study uses a bibliometric technique adopted from several previous studies. The steps taken include, first, using Publish or Perish (PoP) software to find papers or previous research indexed by Scopus related to accrual accounting in government. The results consisted of 200 Scopus indexed papers. The second step is to use the Vos Viewers of tware to visualize or map the findings into an image diagram, based on the 200 papers obtained from PoP. There are 3 image maps produced, namely 1. Network visualization map image, 2. Overlay visualization map image, 3. Density map image visualization. The third step is to document the 200 papers manually based on the theory used, the research methodology (qualitative or quantitative research, participant countries, level of data, variables used). 


\section{Result and Discussion}

Table 1. Scope of research

\begin{tabular}{lll}
\hline Scope & Total & Percentage (\%) \\
\hline Indonesia & 28 & 14 \\
International & 172 & 86 \\
Total & 200 & 100 \\
\hline
\end{tabular}

Based on the research scope, only $14 \%$ of research on government accrual basis was conducted in Indonesia. The remaining $86 \%$ of the research was carried out overseas or internationally. This indicates that there are still very few studies on government accrual accounting in Indonesia so that research is still needed to do this in order to provide theoretical and practical contributions.

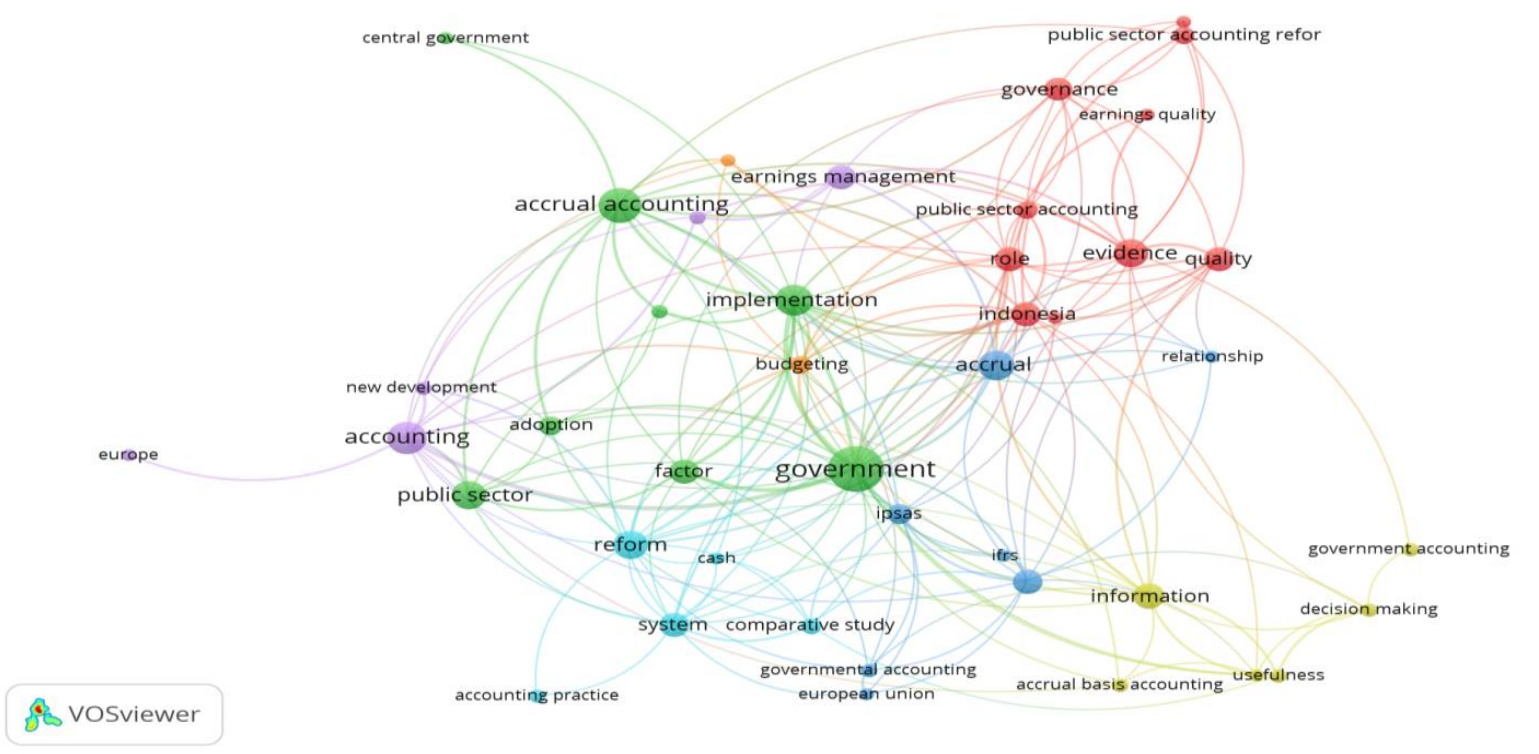

Figure 1. Network Visualization

Based on the Figure 1, Network Visualization, there are 7 clusters based on color (purple, blue, red, green, turquoise, yellow, light green). In table 2 below are cluster groupings:

Table 2. Research Clusters related to Government Accrual Accounting

\begin{tabular}{|l|l|l|}
\hline CLUSTER & MAIN VARIABLE & SUPPORTING VARIABLE \\
\hline 1 (Red) & Earning quality & $\begin{array}{l}\text { Evidence, governance, Indonesia, Public sector accounting, } \\
\text { quality, role, srilanka, turkey }\end{array}$ \\
\hline 2 (Green) & Accrual accounting & $\begin{array}{l}\text { Adoption, Central government, factor, government, } \\
\text { implementation, Indonesian local government, public sector }\end{array}$ \\
\hline 3 (Blue) & Financial reporting & $\begin{array}{l}\text { Accrual, european union, governmental accounting, IPSAS, } \\
\text { relationship }\end{array}$ \\
\hline 4 (Light green) & Decision making, usefulness & $\begin{array}{l}\text { Accrual basis accounting, decision making, government } \\
\text { accounting, information }\end{array}$ \\
\hline 5 (Purple) & Accounting, new development & China, earning management, Europe \\
\hline 6 (Turqoise) & Accounting practice & Cash, comparative study, reform, system \\
\hline 7 (Yellow) & Budgeting & Germany \\
\hline
\end{tabular}




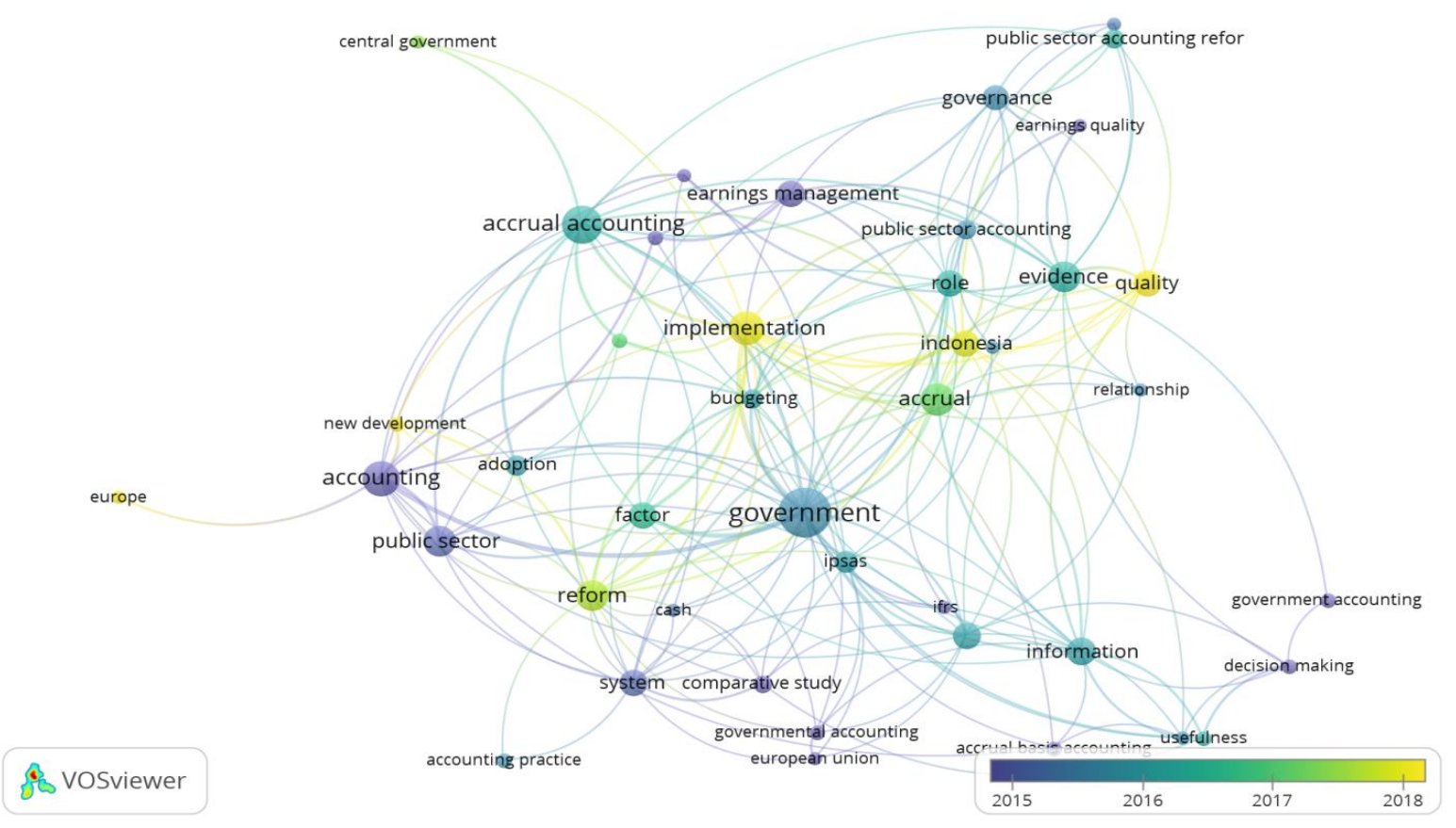

Figure 2. Overlay visualization

This Figure 2. Overlay Visualization, shows that research in this field has been widely researched since 2015 . The brighter the color indicates the more updated research or research is the latest year. Research in 2015 related to accounting, earning management, public sector, systems, government accounting, continued the following year in 2016 and 2017 namely the theme of information, adoption, budgeting, comparative study, accrual accounting, cash. Updated again in 2018 with the theme accrual, reform, new development, implementation, and quality.

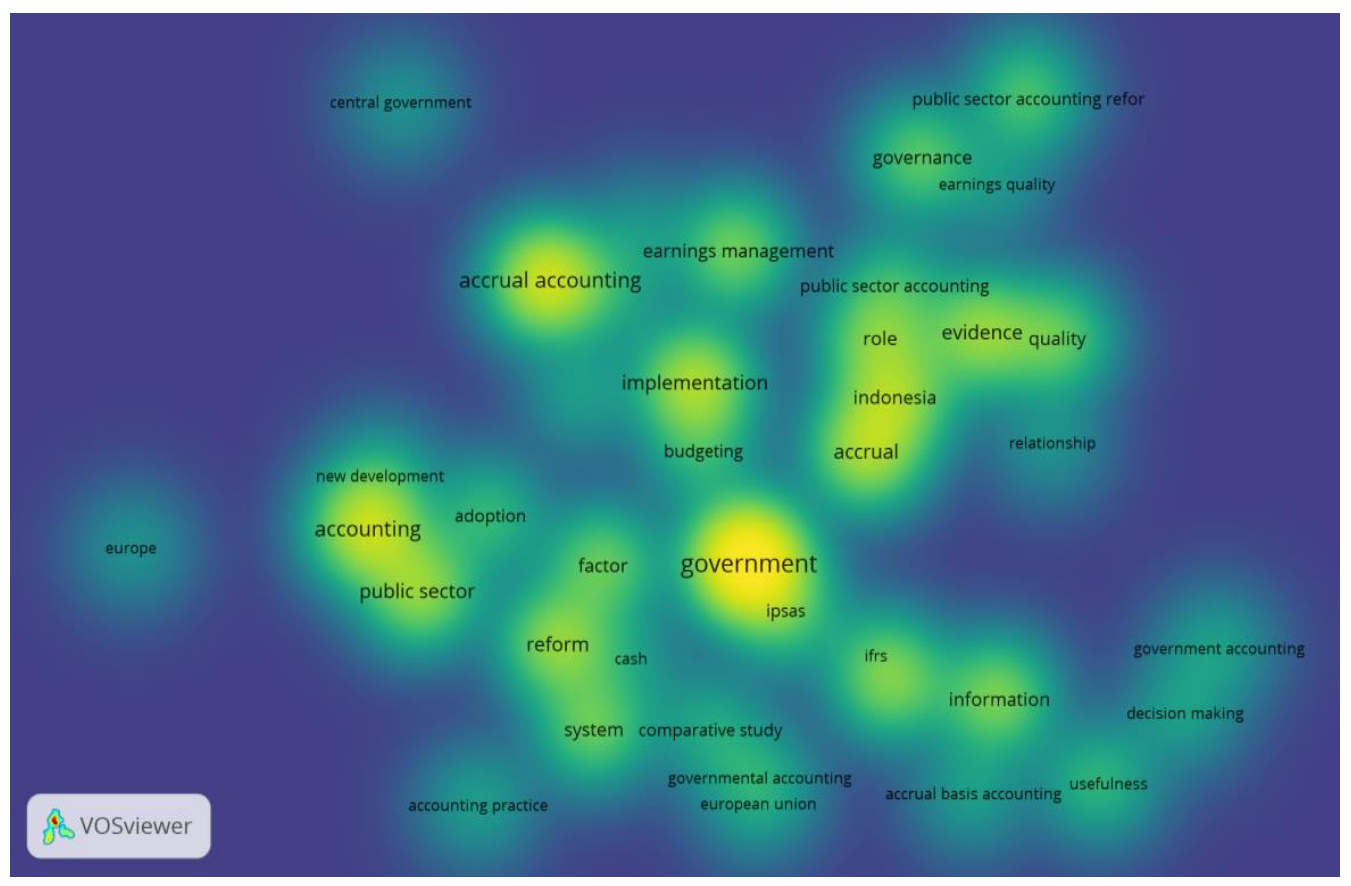

Figure 3. Density Visualization

This image in Figure 3. Density Visualization, shows the depth of discussion. The light section shows a theory that has been long used or is a well-established theory, namely public sector accounting, Government, accrual accounting. The variables currently being discussed include implementation, budgeting, role, quality, reform. The dark part shows that theories that have been used recently or are currently developing but not yet widely 
used, including accounting practices, governmental accounting, accrual basis accounting, usefulness, decision making, governmental accounting, earning management, systems, comparative studies, information, cash.

\section{Conclusion}

Based on the results of this bibliometric research taken in the last 20 years, there are 7 research groups related to government accrual accounting. The latest research related to government accounting is comparing the application of accrual accounting between countries. In addition, previous research study is also conducted both qualitative and quantitative to prove the benefits of government accrual accounting for decision making. Apart from the limitations of accrual accounting that are vulnerable to manipulation by politicians, accrual accounting is needed in the era of new public management to produce relevant and accountable information. For that we need supervision by the government in the application of government accrual accounting.

\section{Implications / limitations and suggestions for further research}

Further research still requires both qualitative and quantitative research to be able to contribute to theory development and solve problems related to the application of accounting bases to the government or public sector.

\section{References}

[1] H. Harun and P. Robinson, The adoption of accrual accounting in the Indonesian public sector, vol. 10. Elsevier, 2010.

[2] N. Hyndman and C. Connolly, "Accruals accounting in the public sector: A road not always taken," Manag. Account. Res., 2011, [Online]. Available: https://www.sciencedirect.com/science/article/pii/S1044500510000880.

[3] H. W. Lampe, D. Hilgers, and C. Ihl, "Does accrual accounting improve municipalities' efficiency? Evidence from Germany," Appl. Econ., vol. 47, no. 41, pp. 4349-4363, 2015, doi: 10.1080/00036846.2015.1030562.

[4] Sylvia, E. G. Sukoharsono, Y. W. Prihatiningtias, and Roekhuddin, "Public interest and accrual accounting: are they aligned?," J. Account. Organ. Chang., vol. 14, no. 4, pp. 366-380, 2018, doi: 10.1108/JAOC-10-2017-0094.

[5] J. Mack and C. Ryan, "Reflections on the theoretical underpinnings of the general-purpose financial reports of Australian government departments," Accounting, Audit. Account. J., vol. 19, no. 4, pp. 592-612, 2006, doi: $10.1108 / 09513570610679146$

[6] S. Cohen, S. Karatzimas, and V. C. Naoum, "The sticky cost phenomenon at the local government level: Empirical evidence from Greece," J. Appl. Account. ..., 2017, [Online]. Available: https://www.emerald.com/insight/content/doi/10.1108/JAAR-03-2015-0019/full/html.

[7] J. Guthrie, "Application of Accrual Accounting in the Australian Public Sector - Rhetoric or Reality," Financ. Account. Manag., vol. 14, no. 1, pp. 1-19, 1998, doi: 10.1111/1468-0408.00047.

[8] N. Hepworth, "Debate: Implementing advanced public financial management reform in developing countries," Public Money Manag., 2015, [Online]. Available: https://www.tandfonline.com/doi/full/10.1080/09540962.2015.1047261.

[9] I. Lapsley and J. Pallot, "Accounting, management and organizational change : A comparative study of local government," no. May 1997, pp. 213-229, 2000, doi: 10.1006/mare.2000.0129.

[10] C. Martí and Y. Kasperskaya, "Public Financial Management Systems and Countries' Governance: A Cross-Country Study," Public Adm. ..., 2015, [Online]. Available: https://onlinelibrary.wiley.com/doi/abs/10.1002/pad.1711.

[11] S. P. da S. Nogueira and S. M. F. Jorge, "The perceived usefulness of financial information for decision making in Portuguese municipalities,” J. Appl. Account. ..., 2017, [Online]. Available: https://www.emerald.com/insight/content/doi/10.1108/JAAR-05-2014-0052/full/html.

[12] G. Walker, J. A. C. Baum, and F. Dobbin, Economics Meets Sociology in Strategic Management, vol. 47, no. 2. 2002. 